\title{
Intrathecal Autologous Bone Marrow Derived Mesenchymal Stem Cells for Ischemic Stroke: Short Term Safety and Efficacy Study
}

\author{
Abo Elkheir W. ${ }^{1,}$, , Reda M. A. ${ }^{2}$, Montaser I. A. ${ }^{2}$, Salem A. E. ${ }^{2}$, Sakr M. A. ${ }^{2}$ \\ ${ }^{1}$ Military Medical Academy, Immunology Department, Cairo, Egypt \\ ${ }^{2}$ Azhar University, Neurology Department, Cairo, Egypt
}

Email address:

dr.wael2008@yahoo.com (Abo E.W.)

To cite this article:

Abo Elkheir W., Reda M. A., Montaser I. A., Salem A. E., Sakr M. A.. Intrathecal Autologous Bone Marrow Derived Mesenchymal Stem Cells for Ischemic Stroke: Short Term Safety and Efficacy Study. American Journal of Bioscience and Bioengineering. Special Issue: Stem Cells for Neuro-regeneration: Where Do We Stand?. Vol. 4, No. 4-1, 2015, pp. 1-6. doi: 10.11648/j.bio.s.2015030401.11

\begin{abstract}
Background: Preclinical and animal studies provide considerable hope for stem cell therapy in cerebrovascular stroke. This study was designed as a pilot study to explore this provisional data. Autologous bone marrow derived mesenchymal stem cells were chosen due to their proven angiogenic, paracrine and neuroregenerative functions. Subjects and Methods: The present study included 32 patients with ischemic stroke fulfilling the following criteria: Inclusion Criteria: 1. Patients with established stroke in the distribution of the middle cerebral artery territory. 2. Six months at least after the onset of acute ischemic stroke. 3. CT brain at the onset denoting acute ischemic stroke. Exclusion Criteria: 1. Hemorrhagic stroke. 2. Conditions which mimick stroke,e.g., multiple sclerosis, vasculitis, arteriovenous malformations, trauma, tumours. Patients were randomly divided into control group (11 patients) and study group (21 patients) which was further divided according to the time between the onset of the stroke and the beginning of the study into: Group I : onset of the stroke and the beginning of the study :6-12 months( 12 patients: 6 males and 6 females). Group II: onset of stroke and the beginning of the study :13-36 months (9 patients: 5 males and 4 females). Control Group: 11 stroke patients : 6 males and 5 females. Time from onset of stroke to beginning of the study ranged from 6-30 months. Both study and control group were subjected to thorough clinical and laboratory assessment, CT brain, National institutes of Health Stroke Scale (NIHSS) and th Barthel active daily life (ADL) scale at the start of therapy, and at 1,3,6 and 12 months after the start of therapy. Stem Cell Injection: 10 million autologous bone marrow-derived MSCs were injected via lumbar puncture in the study group. Results and Conclusions: Changes in Follow-up Parameters: 1. Changes in NIHSS score: Control group showed non-significant decrease in NIHSS score starting from the $3^{\text {rd }}$ month. On the other hand, study group showed highly significant decrease in NIHSS score starting from $6^{\text {th }}$ month, more in group I. 2. Changes in ADL score: ADL score showed non-significant increase starting from $3^{\text {rd }}$ month in the control group, while it showed a highly significant increase in the study group starting from $6^{\text {th }}$ month, more pronounced in group I. Intrathecal administration of MSCs is safe and enhances regeneration in ischemic stroke patients.
\end{abstract}

Keywords: Mesenchymal Stem Cells, Stem Cell Therapy, Ischemic Stroke, Neuroregeneration

\section{Introduction}

Stroke is one of the leading causes of death worldwide, with approximately 15 million victims each year. Paradoxically, and despite this high mortality, $76 \%$ of stroke patients survive, suffering from variable disability (1).

The pathologic changes occurring in stroke are precipitated by the reduction in oxygen and glucose availability, resulting in apoptosis through a number of mechanisms (2). Subsequent reperfusion causes the egress of inflammatory leukocytes and activation of chemokines such as IL-8 and monocyte chemotactic protein-1 (3). Leucocytes secrete reactive oxygen species and metalloproteinases which may augment tissue damage. Inflammatory response is then limited through local anti-inflammatory mediators such as annexin A1 and lipoxin A4 which promote apoptosis and phagocytosis of resident leukocytes releasing antiinflammatory cytokines suh as IL-6 and IL-10 (4). This complex pathogenesis opens the door to a variety of 
proposed therapeutic agents all under trial.

Current therapeutic modalities for stroke is far from satisfactory. The only accepted treatment for ischemic stroke is tissue plasminogen activator administered within 3 hours of the incident (5). Trials exploring the use of NMDA antagonists (6) to block initial triggering of apoptosis, thrombin inhibitors for secondary prevention (7) as well as prevention of leukocyte recruitment through ICAM inhibitors ( $8 \& 9)$ have been described.

Ideally, therapeutic approaches should target stopping cell death and stimulation of tissue regeneration. The ultimate goal of cellular therapy for stroke is to replace dead neurons, remyelinate severed axons and repair damaged neural circuits (10). The potential of stem cell therapy in tissue regeneration is backed by extensive evidence in animal and human studies. The mechanisms of stem cell induced regeneration include activation of endogenous neurogenesis (11), secretion of trophic factors (12), enhancement of cerebral angiogenesis(13) or transdifferentiation into target cells (14).

Stem cells are a diverse entity with variable sources and functions. Endothelial(15), fetal neural stem cells (16), mesenchymal stem cells (MSCs) (17-20) and induced pluripotent stem cells (21) were proposed as possible therapeutic candidates. However, for ethical and immunological privileges, adult mesenchymal stem cells were the cells of choice. MSCs represent a population of multipotent adult stem cells that can be isolated from many tissues, most commonly bone marrow and adipose tissue. MSCs exhibit a number of properties that make them ideal candidates for cellular therapy. First: MSCs can be isolated and expanded to give the needed therapeutic dose. Second: they show remarkable transdifferentiation ability, even to tissues outside their normal repertoire : osteoblasts, chondroblasts and adipocytes. Third: they stimulate angiogenesis. Fourth: they secrete a number of cytokines enhancing regeneration and reducing apoptosis. Lastly, they stimulate proliferation and differentiation of endogenous stem cells $(17-20)$.

The aim of the present work is to assess the efficacy of bone marrow-derived mesenchymal stem cell therapy in ischemic stroke patients by intrathecal injection.

\section{Materials and Methods}

The present study included thirty two patients with ischemic stroke. After Institutional Review Board approval, patients were recruited randomly from Al-Hussein and Sayed Galal University Hospitals, Neurology department. Patients fulfilled the following criteria:

\subsection{Inclusion Criteria}

1. Patients with established stroke in the distribution of the middle cerebral artery territory.

2. Six months at least after the onset of acute ischemic stroke

3. CT brain at the onset denoting acute ischemic stroke.

\subsection{Exclusion Criteria}

1. Hemorrhagic stroke

2. Conditions which mimick stroke,e.g., multiple sclerosis, vasculitis, arteriovenous malformations, trauma, tumours.

After signing informed consent, patients were randomly assigned to study and control groups.

\subsection{Study Group}

Which was subdivided according to the time between the onset of the stroke and the beginning of the study into two groups:

Group I : in which the time between the onset of the stroke and the beginning of the study was 6-12 months. This group included 12 patients: 6 males and 6 females.

Group II: in which the time between the onset of stroke and the beginning of the study was 13-36 months. This group included 9 patients: 5 males and 4 females.

\subsection{Control Group}

Included 11 stroke patients : 6 males and 5 females. Time from onset of stroke to beginning of the study ranged from 630 months, with the same inclusion and exclusion criteria as the study group.

Both study and control group were subjected to the following :

- Thorough clinical assessment including detailed history taking and complete general and neurological examination.

- National institutes of Health Stroke Scale (NIHSS) and th Barthel active daily life (ADL) scale will be done at the start of therapy, and at 1,3,6 and 12 months after the start of therapy.

- CT brain

- Routine laboratory tests ,e.g., complete blood picture $(\mathrm{CBC})$, erythrocyte sedimentation rate (ESR), liver function tests, PT, PTT, lipid profile, uric acid.

\subsection{Stem Cell Isolation}

- Under complete aseptic conditions and local anesthesia, $60 \mathrm{ml}$ of bone marrow were aspirated from the posterior iliac spine on preservative free heparin.

- Mononuclear cells were separated by density gradient centrifugation using ficol-hypaque density 1077.

- Mononuclear cells were seeded in T25 flasks in the presence of antibiotics and antimycotics in DMEM. Flasks were incubated at $37^{\circ} \mathrm{C}$ in $5 \% \mathrm{CO} 2$ incubator.

- After 48 hours, non-adherent cells were removed, complete medium added, and medium was changed every 3 days.

- Flasks were examined using inverted microscope until $80-90 \%$ confluence.

- Adherent cells were removed using Trypsin-EDTA digestion.

- Cells were washed, counted and tested for viability. 
- MSCs were identified using flow cytometry

- Cell density was adjusted to 2 million/ml

\subsection{Characterization of the Stem Cells Injected}

MSCs were identified according to the minimal criteria proposed by the International Society of Cell Therapy which are: morphology, immunophenotyping (was done using the MSC identification kit (R\&D)) and trilineage differentiation potential.

\subsection{Stem Cell Injection}

Under aseptic conditions, 10 million MSCs were injected via lumbar puncture.

\subsection{Statistical Methods}

Statistical analysis was done using mean, standard error, student t-test and chi-square by SPSS v 17. Pearson;s correlation test was used. Significant result was considered if $\mathrm{p} \leq 0.05$, highly significant result is considered if $\mathrm{p} \leq 0.01$.

\section{Results:}

\subsection{Initial Evaluation}

Demographic characteristics of the patient and control groups are listed in Table (1).

Table (1). Demographic Characteristics of the Study Population.

\begin{tabular}{|c|c|c|c|c|c|c|c|c|c|}
\hline & \multicolumn{2}{|l|}{ Age } & \multicolumn{2}{|l|}{ Sex } & \multirow{2}{*}{ DM } & \multirow{2}{*}{ HTN } & \multirow{2}{*}{ IHD } & \multirow{2}{*}{ Hyperlipidemia } & \multirow{2}{*}{ Hyperuricemia } \\
\hline & Range & Mean \pm SD & Male & Female & & & & & \\
\hline Control & $\begin{array}{l}38.0- \\
70.0\end{array}$ & $58.91 \pm 9.18$ & $\begin{array}{l}6 \\
54.6 \%\end{array}$ & $\begin{array}{l}6 \\
50.0 \%\end{array}$ & $\begin{array}{l}8 \\
72.7 \%\end{array}$ & $\begin{array}{l}9 \\
81.8 \%\end{array}$ & $\begin{array}{l}5 \\
45.5 \%\end{array}$ & $\begin{array}{l}5 \\
45.5 \%\end{array}$ & $\begin{array}{l}4 \\
36.4 \%\end{array}$ \\
\hline Group I & $\begin{array}{l}38.0- \\
66.0\end{array}$ & $55.58 \pm 8.54$ & $\begin{array}{l}6 \\
50.0 \%\end{array}$ & $\begin{array}{l}4 \\
44.4 \%\end{array}$ & $\begin{array}{l}7 \\
58.3 \%\end{array}$ & $\begin{array}{l}10 \\
83.3 \%\end{array}$ & $\begin{array}{l}5 \\
41.7 \%\end{array}$ & $\begin{array}{l}3 \\
25.0 \%\end{array}$ & $\begin{array}{l}3 \\
25.0 \%\end{array}$ \\
\hline $\begin{array}{l}\text { Group II } \\
\text { P }\end{array}$ & $\begin{array}{l}47.0- \\
70.0 \\
0.40\end{array}$ & $60.44 \pm 6.98$ & $\begin{array}{l}5 \\
55.6 \% \\
0.92\end{array}$ & $\begin{array}{l}17 \\
53.1 \%\end{array}$ & $\begin{array}{l}8 \\
88.9 \%\end{array}$ & $\begin{array}{l}6 \\
66.7 \%\end{array}$ & $\begin{array}{l}3 \\
33.3 \%\end{array}$ & $\begin{array}{l}5 \\
55.6 \%\end{array}$ & $\begin{array}{l}2 \\
22.2 \%\end{array}$ \\
\hline
\end{tabular}

$\mathrm{DM}=$ Diabetes Mellitus

HTN=Hypertension

$\mathrm{IHD}=$ Ischemic heart disease

$\mathrm{CD} 90$
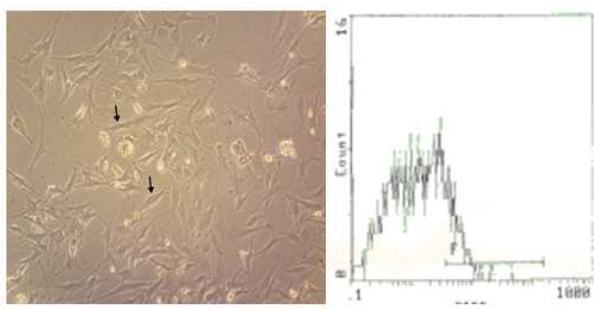

CD34

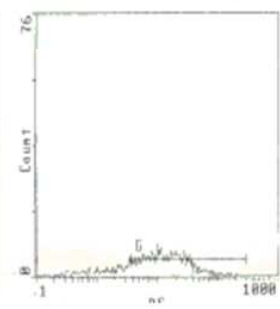

$\mathrm{CD} 271$

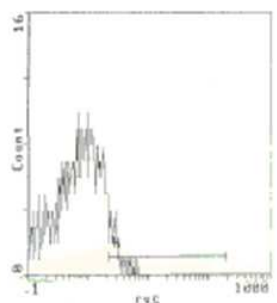
a) MSC morphology
b. Immunophenotyping

Figure (1). Identification of Mesenchymal Stem Cells.

Table (2) shows the initial clinical evaluation of the study group.

Table (2). Initial Clinical Parameters.

\begin{tabular}{llll}
\hline & $\begin{array}{l}\text { Time of onset } \\
\text { (months) }\end{array}$ & NIHSS Score & ADL score \\
\hline Control & $16.73 \pm 9.12$ & $11.36 \pm 5.46$ & $12.91 \pm 3.42$ \\
Group I & $9.83 \pm 1.80$ & $11.42 \pm 5.12$ & $11.33 \pm 2.10$ \\
Group II & $22.67 \pm 8.20$ & $9.56 \pm 2.92$ & $11.22 \pm 3.15$ \\
\hline
\end{tabular}

\subsection{Characterization of the Stem Cells Injected}

Morphology and immunophenotyping of the cells is shown in Figure (1).

\subsection{Changes in Follow-up Parameters}

\subsubsection{Changes in NIHSS Score}

Control group showed non-significant decrease in NIHSS score starting from the $3^{\text {rd }}$ month. On the other hand, both study groups (I \& II) showed highly significant decrease in NIHSS score starting from $6^{\text {th }}$ month (Table $\left.3 a, b, c\right)$, Figure (2).

Table (3a). Changes in NIHSS score in Control group over the follow-up period.

\begin{tabular}{lllll}
\hline \multirow{2}{*}{ NIHSS } & Range & Mean \pm SD & \multicolumn{2}{l}{ Paired T-test } \\
\cline { 5 - 5 } & & & t-test & p-value \\
\hline Base line & $7.0-22.0$ & $11.4 \pm 5.5$ & & \\
1 month & $5.0-21.0$ & $11.1 \pm 5.3$ & 1.399 & 0.192 \\
3 months & $5.0-20.0$ & $10.5 \pm 5.5$ & 2.085 & 0.064 \\
6 months & $5.0-20.0$ & $10.5 \pm 5.5$ & 2.085 & 0.064 \\
9 months & $5.0-20.0$ & $10.5 \pm 5.5$ & 2.085 & 0.064 \\
12 months months & $5.0-20.0$ & $10.5 \pm 5.5$ & 2.085 & 0.064 \\
\hline
\end{tabular}


Table (3b). Changes in NIHSS score in Study group I over the follow-up period.

\begin{tabular}{lllll}
\hline \multirow{2}{*}{ NIHSS } & \multirow{2}{*}{ Range } & \multirow{2}{*}{ Mean } & \multicolumn{2}{c}{ Paired T-test } \\
\cline { 4 - 5 } & & & t-test & p-value \\
\hline Base line & $7.0-22.0$ & $11.4 \pm 5.1$ & & \\
1 month & $5.0-21.0$ & $9.6 \pm 5.3$ & 5.698 & 0.000 \\
3 months & $3.0-20.0$ & $8.8 \pm 5.6$ & 9.940 & 0.000 \\
6 months & $3.0-20.0$ & $8.1 \pm 5.8$ & 10.761 & 0.000 \\
9 months & $3.0-20.0$ & $8.1 \pm 5.8$ & 10.761 & 0.000 \\
12 months & $3.0-20.0$ & $8.1 \pm 5.8$ & 10.761 & 0.000 \\
\hline
\end{tabular}

Table (3c). Changes in NIHSS score in Study group II over the follow-up period.

\begin{tabular}{lllll}
\hline \multirow{2}{*}{ NIHSS } & \multirow{2}{*}{ Range } & \multirow{2}{*}{ Mean } & \multicolumn{2}{c}{ Paired T-test } \\
\cline { 4 - 5 } & & & t-test & p-value \\
\hline Base line & $7.0-15.0$ & $9.6 \pm 2.9$ & & \\
1 month & $6.0-15.0$ & $8.9 \pm 3.0$ & 1.789 & 0.111 \\
3 months & $6.0-15.0$ & $8.9 \pm 3.0$ & 1.789 & 0.111 \\
6 months & $5.0-15.0$ & $8.4 \pm 3.2$ & 2.169 & 0.062 \\
9 months & $5.0-15.0$ & $8.4 \pm 3.2$ & 2.169 & 0.062 \\
12 months & $5.0-15.0$ & $8.4 \pm 3.2$ & 2.169 & 0.062 \\
\hline
\end{tabular}

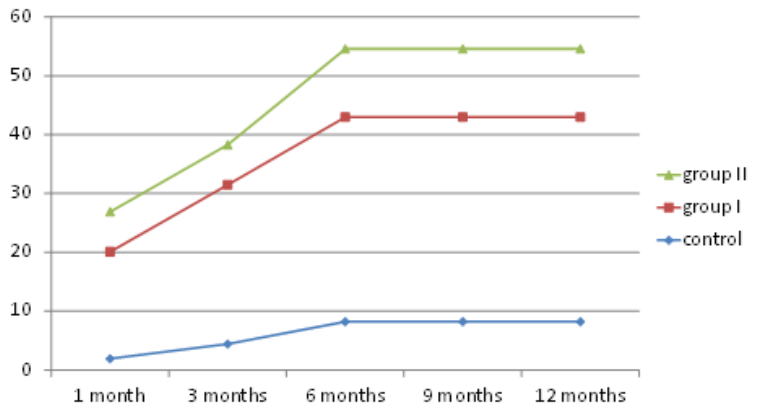

Figure (2). Difference in Percentage of change in NIHSS score between patients and control.

\subsubsection{Changes in ADL Score}

ADL score showed non significant increase starting from 3rd month in the control group, while it showed a highly significant increase in both groups I and II starting from 6th month Table $(5 \mathrm{a}, \mathrm{b}, \mathrm{c})$.

Table (4a). Changes in ADL scores in the control groups over the follow-up period.

\begin{tabular}{lllll}
\hline \multirow{2}{*}{ ADL } & Control & \multicolumn{3}{l}{ Paired T-test } \\
\cline { 2 - 5 } & Range & Mean & t & p-value \\
\hline Base line & $5.0-18.0$ & $12.91 \pm 3.42$ & & \\
1 month & $5.0-18.0$ & $13.18 \pm 3.28$ & -1.399 & 0.192 \\
3 months & $5.0-18.0$ & $13.46 \pm 3.39$ & -1.936 & 0.082 \\
6 months & $5.0-18.0$ & $13.82 \pm 3.63$ & -2.319 & 0.043 \\
9 months & $5.0-18.0$ & $13.82 \pm 3.63$ & -2.319 & 0.043 \\
12 months & $5.0-18.0$ & $13.82 \pm 3.63$ & -2.319 & 0.043 \\
\hline
\end{tabular}

Table (4b). Changes in ADL scores in the Study group I over the follow-up period.

\begin{tabular}{lllll}
\hline \multirow{2}{*}{ ADL } & Group I & \multicolumn{3}{c}{ Paired T-test } \\
\cline { 2 - 4 } & Range & Mean & t & p-value \\
\hline Base line & $9.0-15.0$ & $11.33 \pm 2.10$ & & \\
1 month & $9.0-15.0$ & $12.83 \pm 1.75$ & -.3 .000 & 0.012 \\
3 months & $8.0-17.0$ & $13.50 \pm 2.65$ & -3.120 & 0.010 \\
6 months & $8.0-18.0$ & $14.17 \pm 2.76$ & -4.444 & 0.001 \\
9 months & $8.0-18.0$ & $14.33 \pm 2.90$ & -4.062 & 0.002 \\
12 months & $8.0-18.0$ & $14.33 \pm 2.90$ & -4.062 & 0.002 \\
\hline
\end{tabular}

Table (4c). Changes in ADL scores in the Study group II over the follow-up period.

\begin{tabular}{lllll}
\hline \multirow{2}{*}{ ADL } & Group II & \multicolumn{3}{c}{ Paired T-test } \\
\cline { 2 - 5 } & Range & Mean \pm SD & t & P-value \\
\hline Base line & $5.0-15.0$ & $11.22 \pm 3.15$ & & \\
1 month & $5.0-15.0$ & $11.56 \pm 3.25$ & -1.414 & 0.195 \\
3 months & $5.0-15.0$ & $11.56 \pm 3.25$ & -1.414 & 0.195 \\
6 months & $5.0-15.0$ & $12.22 \pm 3.73$ & -2.449 & 0.040 \\
9 months & $5.0-15.0$ & $12.22 \pm 3.73$ & -2.449 & 0.040 \\
12 months & $5.0-15.0$ & $12.22 \pm 3.73$ & -2.449 & 0.040 \\
\hline
\end{tabular}

Comparing the three study groups, the percentage of changes in NIHSS and ADL scores are shown in figure (3).

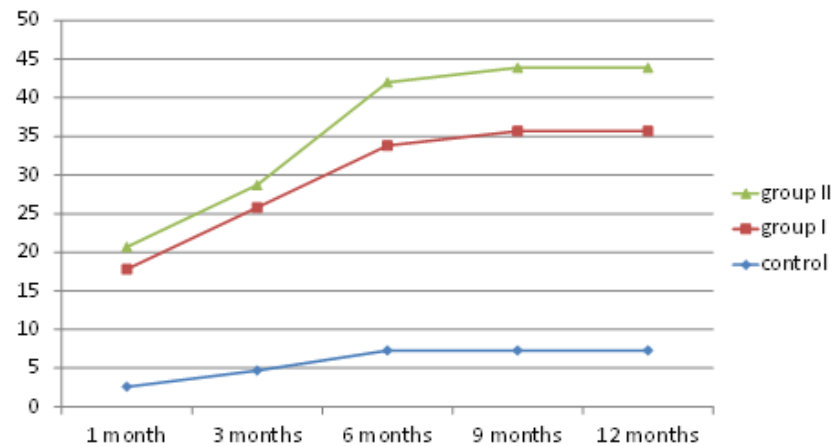

Figure (3). Difference in Percentage of change in ADL score between patients and control.

\section{Discussion}

Current management of ischemic stroke focuses on preservation of tissue perfusion through recanalization or tissue plasminogen activator administration. Approach to neuronal repair is essential to minimize disability after ischemic insult (22). Cellular therapy is emerging as a potentially important line of therapy in both neuroprotection and neuroregeneration. The use of MSC is superior to other bone marrow cells such as CD34+ve cells and endothelial progenitors in many aspects: easier isolation protocols, more efficient expansion, in addition to the wider spectrum of activity covering all of the mechanisms of cellular induction of neuroregeneration (23). MSCs are also superior to neural stem cells as they are autologous, eliciting no immune response. Moreover, MSCs can function as stimulant of angiogenesis, anti-apoptotic and paracrine action; which is not applicable with neural stem cells.

A number of clinical trials were designed to evaluate the efficacy of cellular therapy in ischemic stroke. These trials explored a number of variables namely cell type, source, route of administration and cell dose. Cell types used were mesenchymal stem cells ,CD34+ve cells, neural stem cells, endothelial and mononuclear cells. Source of the cells were allogenic, or autologous cells, bone marrow, umbilical cord blood or adipose tissue. Route of administration is either systemic intra-arterial, intra-carotid, or intracerebral. Cell dose ranged from 2 to $20 \times 10^{6}(23,24)$ 
In a trial to reach consensus on cellular therapy for stroke patients, STEPS I and II guidelines were proposed regarding clinical trial setting: patient selection, cell type, dosing and route of administration in stem cell therapy for stroke (25) .

This study was designed to evaluate the safety and short term efficacy of autologous bone marrow derived mesenchymal stem cell therapy delivered intrathecally in cases of ischemic stroke. In this study, evaluation was done using NIHSS score an ADL scale. Collective patient group showed improvement in $\mathrm{NIH}+\mathrm{SS}$ and ADL scores starting from first month and steadily improving until stabilizing starting from $6^{\text {th }}$ month. This improvement showed statistically significant difference from the control group. However, the improvement was not significant in group II (chronic group). when studied alone.

The difference in therapeutic improvement between acute and chronic groups may be due to the weaning of the inflammatory and apoptotic signals in the chronic phase, which form the main chemotactic molecules enhancing homing and proliferation of injected stem cells.

The mechanism of therapeutic action of stem cells in neuronal injury is most probably a combination of functions: reduction of apoptosis and hence inflammatory response, stimulation of endogenous neurogenesis, induction of angiogenesis and formation of new neuronal connections (23) in addition to the paracrine action (26).

In this work, the choice of bone marrow derived MSCs was because of the extensive literature documenting their effectiveness in all the proposed mechanisms of actions in neuroregeneration (27).

MSCs were isolated from autologous bone marrow as this is the least invasive and safest source (28).

The intrathecal route of administration was chosen because of the simplicity, safety, and proven efficacy in other cerebral trials (29).

Doeppner and Hermann (2014) performed critical review of the clinical trials conducted using stem cell therpy for ischemic stroke (24). Trials conducted using MSCs reported safety and feasibility (Bang et al, Bhasin et al 2011,2013, Honmou et al 2011, Savitz et al 2011 30-34)). All these trials used the intravenous route for cell delivery. However, homing of MSCs into the brain is limited (35), necessitating the search for other more effective routes for cell delivery. Suarez-Monteagudo et al, 2009 reported transplantation of MSCs sterotactically in five stroke patients with functional improvement seen after one year (36).

The only trial reporting the use of intrathecal route for cell delivery is that of Reabinovich et al (2005) who used a poorly identified cell population consisting of a mixture of immature nervous and hemopoeitic cells (37).

No adverse events were encountered, apart from mild headache which responded to regular analgesics

This work documents the positive therapeutic effect of stem cell therapy in ischemic stroke patients introducing a simple setting of autologous, bone marrow derived MSCs injected intrathecally.

\section{Conclusions}

Autologous bone marrow derived MSC therapy represent a safe therapeutic measure in ischemic stroke. Intrathecal route is an effective route of stem cell adminstration, especially in early cases. The improvement is more in recent cases.

\section{References}

[1] Smith H and Gavins F (2012): The potential of stem cell therapy for stroke: is PISCES the sign? FASEB 26(6):2239225

[2] Mattson MP, Culmsee C, and Yu ZF (2000): Apoptotic and antiapoptotic mechanisms in stroke. Cell Tissue Res 301:173187.

[3] Gravins FN, Dalli J, Flower RJ, Granger DN andPerretti M (2007): Activation of annexin-1 counter-regulatory circuit affords protection in the mouse brain microcirculation. FASEB 121:1751-1758.

[4] Matsuo Y, Onodera H, Shiga Y, Shozuhara H, Ninomiya M, Kihara T, Tamatani T, Miyasaka M and Kogure K (1994): Role of cell adhesion molecules in brain injury after transient middle cerebral artery occlusion in the rat. Brain Res 656:344-352.

[5] Saver JL, Fonarrow GC, Smith EE, Reeves MJ, GrauSepulveda MV, Pan W, Oslon DM, Hernandez AF, Peterson ED, Schwamm LH (2013): Time to treatment with intravenous tissue plasminogen activator and outcome from acute ischemic stroke. JAMA 309(23):2480-2488.

[6] Morris GF, Bullock R, Marshall SB, Marmarou A, Maas A, and Marshall F (1999): Failure of the competitive N-methylD-aspartate antagonist selfotel (CGS19755) in the treatment of severe head injury: results of two phase III clinical trials. The selfotel investigaors. J.Neurosurg 91:737-743.

[7] Olsson SB (2003): Stroke prevention with the oral direct thrombin inhibitor zimelagatran compared with warfarin in patients with non-valvular atrial fibritllation (SPORTIF III): randomied controlled trial. Lancet 362:1691-169

[8] EAST (2001): Use of anti-ICAM-1 therapy in ischemic stroke: results of the Enlimornab Acute Stroke Trial. Neurology $57: 1428-1434$.

[9] Holloway PM, Smith HK, Renshaw D, Flower RJ, Getting SJ and Gavins FN (2011): Targeting the melanocortin receptor system for anti-stroke therapy. Trends Pharmacol. Sci 32:90-98.

[10] Stankowski JN and Gupta R (2010): Therapeutic Targets for Neuroprotection in Acute Ischemic Stroke: Lost in Translation? AntioxidRedox Signal 14(10):1841-1851.

[11] Zheng Z and Chopp M (2009): Neurorestorative therapies for stroke: underlying mechanisms and translation to the clinic. Lancet Neurol 8(5): 491-500.

[12] Joyce N, Annett G, Wirthlin L, Oslon S, Bauer G and Nolta (2010): Mesenchymal stem cells for the treament of neurodegenerative disease. Regen Med 5(6):933-946.

[13] Jiang Q, Zhang ZG, Ding GL, Zhang L, Ewing JR, Wang L, Zhang R, Li L Lu M, Meng H, Arbab AS, Hu J, LiQ (2005): Investigation of neural progenitor cell induced angiogenesis after embolic stroke in rat using MRI. Neuroimage 28:698-70 
[14] Heo JS, Choi SM, Kim HO, Kim EH, You J, Park T, Kim E, Kim HS (2013): Neural transdifferentiation of human bone marrow mesenchymal stem cells on hydrophobic polymermodified surface and therapeutic effects in an animal model of ischemic stroke. Neuroscience 15:238-305.

[15] Wang L, Zhang ZG, Zhang RL, Gregg SR, Hozeska-Solgot A, LeTourneau Y, Wang Y , Chopp M (2006): Matrix metalloproteinase 2 (MMP2) and MMP9 secreted by erythropoeitin-activated endothelial cells promote neural progenitor cell migration. J Neurosci 26:5996-6003.

[16] Roitbak T, Li L, Cunningham LA (2008): Neural stm/progenitor cells promote endothelial cell morphogenesis and protect endothelial cells against ischemia via HIF-1-alpharegulated VEGF signaling. J Cereb Blood Flow Metab. 28:1530-42.

[17] Shen LH, Li Y, Chen J, Zacharek A, Gao Q, Kapke A, Lu M, Raginski K, Vanguri P, Smith A, Chopp M (2007): Therapeutic benefit of bone marrow stromal cells administered 1 month after stroke. J Cereb Blood Flow Metab 27:6-13.

[18] Chen J, Li Y, Katakowski M, Chen X, Wang L, Lu D, Lu M, Gautam SC, Chopp M (2003): Intravenous bone marrow stromal cell therapy reduces apoptosis and promotes endogenous cell proliferation after stroke in female rat. J Neurosci Res 73:778-86.

[19] Wang Y, Deng Y, Zhou GQ (2008): SDF-1 alpha/CXCR4mediated migration of systemically transplanted bone marrow stromal cells towards ischemic brain lesion in a rat model. Brain Res 1195:104-1

[20] Bang OY, Lee JS, Lee PH, Lee G (2005): Autologous mesenchymal stem cell transplantation in

[21] Verma A, Verma N (2011): Induced pluripotent stem cells and promises of neuroregenerative medicine. Neurol India 59(4):555-7.

[22] Zivin JA (2009): Acute stroke therapy with tissue plasminogen activator (tPA) since it was approved by the U.S. Food and Drug Administration (FDA). Ann Neurol 66(1):6-10.

[23] Doeppner TR and Hermann DM (2014): Stem cell-based treatments against stroke: observations from human proof-ofconcept studies and considerations regarding clinical applicability. Front Cell Neurosci 8:35

[24] Banajeree S, Williamson D, Habib N, Chataway J (2012): The potential benefit of stem cell therapy after stroke: an update. Vascular Health and Risk Management 8:569-580.

[25] STEPS Participants (2009): Stem Cell Therapies as an Emerging Paradigm in Stroke (STEPS) Bridging Basic and Clinical Science for Cellular and Neurogenic Factor Therapy in Treating Stroke. Stroke 40:510-515.

[26] Kurozumi K, Nakamura K, Tamiya T, Kawano Y, Ishii K, Kobune M, Hirai S, Uchida H, Sasaki K, Ito Y, Kato K, Honmou O, Houkin K, Date I, Hamada H (2005): Mesenchymal stem cells that produce neurotrophic factors reduce ischemic damage in the rat middle cerebral artery occlusion model. Mol Ther 1:96-10

[27] Sheikh AM, Nagai A, Wakabayashi K, Narantuya D, Kobayashi S, Yamaguchi S, Kim SU (2011): Mesenchymal stem cell transplantation modulates neuroinflammation in focal cerebral ischemia: contribution of fractalkine and ILNeurobiol Dis 41:717-724.

[28] Lee JS, Hong JM, Moon GJ, Lee PH, Ahn YH, Bang OY, STARTING collaborators (2010): A long-term follow-up study of intravenous autologous mesenchymal stem cell transplantation in patients with ischemic stroke. Stem Cells 28(6):1099-106.

[29] El-Kheir WA, Gabr H, Awad MR, Ghannam O, Barakat Y, Farghali HA, El Maadawi ZM, Ewes I, Sabaawy HE. (2014): Autologous bone marrow-derived cell therapy combined with physical therapy induces functional improvement in chronic spinal cord injury patients. Cell Transplant 23(6):729-45.

[30] Bang OY, Lee JS, Lee PH and Lee G (2005): Autologous mesenchymal stem cell transplantation in stroke patients. Ann Neurol 57(6):874-82.

[31] Bhasin A, Srivastava MV, Kumaran SS, Mohanty S, Bhatia R, Bose S, Gaikwad S, GArg A, Airan B (2011): Autologous mesenchymal stem cells in chronic stroke. Cerebrovasc. Dis. Extra 1:93-104.

[32] Bhasin A, Srivastava MV, Mohanty S, Bhatia R, Kumaran SS, Bose S( 2013): Stem Cell therapy a clinical trial of stroke. Clin Neurol Neurosurg 115:1003-1008.

[33] Honmou O, Houkin K, Matsunaga T, Niitsu Y, Ishiai S, Onodera R, Waxman SG, Kocis JD (2011): Intravenous administration of auto serum-expanded autologous mesenchymal stem cells in stroke. Brain 134:1790-1807.

[34] Savitz SI, Misra V, Kasam M, Juneia H, Cox CS Jr, Alderman S, Aisiku I, Kar S, Gee A, Grota JC (2011): Intravenous autologous bone marrow mononuclear cells for ischemic stroke. Ann Neurol 70:59-69.

[35] Barbosa da Fonesca LM, Gutfilen B, Rosado de Castro PH, Battistella V, Goldenberg RC, Kasai-Brunswick T, Chagas CL, Wainberg E, Maiolino A, Salles Xavier S, Andre C, MendezOtero R, de Freitas GR (2010): Migration and homing of bone-marrow mononuclear cells in chroic ischemic stroke after intra-arterial injection. Exp Neurol 221, 122-128.

[36] Suarez-Monteagudo C, Hernandez-Ramirez P, AlvarezGonzalez L, Garcia-Maeso I, de la Cuetara-Bernal K, CastilloDiaz L, Bringas-Vega ML, Martinez-Aching G, MoralesChacon LM, Baez-Martin MM, Sanchez-Catasus C, CarballoBarreda M, Rodriguez-Rojas R, Gomez-fernandez L, AlbertiAmador E, Macias-Abraham C, Balea ED, Rosales LC, Del Valle Perez L, Ferrer BB, Gonzalez RM, Bergado JA (2009): Autologous bone marrow stem cell neurotransplantation in sgroke patients. Restor Neurol Neurosci 27:151-161.

[37] Rabinovich SS, Seledtsov VI, Banul NV, Poveshchenko OV, Senvukov VV, Astrakov SV, Samarin DM, Taraban VY (2005) Cell therapy of brain stroke. Bull Exp Biol Med 139:126-128. 